\title{
ARBUSCULAR MYCORRHIZAL FUNGAL COMMUNITIES IN NATIVE AND IN REPLANTED ARAUCARIA FOREST
}

\author{
Milene Moreira ${ }^{1 *}$; Dilmar Baretta²; Siu Mui Tsai³; Elke Jurandy Bran Nogueira Cardoso ${ }^{4}$ \\ ${ }^{1}$ APTA - Pólo Regional do Médio Paranapanema, C.P. 263 - 19800-970 - Assis, SP - Brasil. \\ ${ }^{2}$ UDESC/CEO - Lab. de Solos , R. Benjamin Constant ,164-D - 89806-070 - Chapecó, SC - Brasil. \\ ${ }^{3}$ USP/CENA - Lab. de Microbiologia e Biologia Molecular, Av. Centenário, 303 - 13416-000 - Piracicaba, SP - \\ Brasil. \\ ${ }^{4}$ USP/ESALQ - Depto. de Ciência do Solo - C.P. 9 - 13418-900 - Piracicaba, SP - Brasil. \\ *Corresponding author <mmoreira@apta.sp.gov.br>
}

\begin{abstract}
Araucaria angustifolia is an important Brazilian conifer, but it is endangered of extinction due to excessive logging. The objective of the present case study was to survey data on the diversity of AMF in Araucaria angustifolia forests, and to learn whether it is possible to discriminate between the AMF communities associated with natural, introduced, and impacted-byanthropogenic-action ecosystems. Three ecosystems representative of the Campos do Jordão (São Paulo State, Brazil) region were selected, as follows: (i) a native climax forest, with predominance of Araucaria trees, without anthropogenic interference (NF), (ii) Araucaria forest introduced in 1959 (RE), and (iii) Araucaria forest introduced in 1958, submitted to accidental fire in July 2001 (RF). Sampling of rhizosphere soil was performed at a 0-20 cm depth around each Araucaria tree, and $2 \mathrm{~m}$ from the trunk, in the months of May and October, 2002. AMF spores were separated from the soil, counted, and taxonomically identified, while the roots were evaluated for mycorrhizal colonization. The ecological indices R (Richness), Is (Simpson's dominance index) and H (Shannon's diversity index) were calculated. All the data were submitted to univariate (two-way ANOVA) and correspondence analysis (CA). Considering both samplings and the three areas, twenty-six AMF species were found, distributed among five genera, Acaulospora and Glomus being the most frequent ones. There were no differences among the three areas for R, Is, and H. CA demonstrated that there is a spatial separation among the three areas, and the AMF that preferentially associated with each area.
\end{abstract}

Key words: AMF, Brazil Pine, diversity, spore density, accidental fire

\section{COMUNIDADES DE FUNGOS MICORRÍZICOS ARBUSCULARES EM FLORESTANATIVAE REPLANTADADE ARAUCÁRIA}

RESUMO: A Araucaria angustifolia é uma importante conífera brasileira, mas encontra-se ameaçada de extinção. Levantaram-se dados sobre a diversidade de fungos micorrízicos arbusculares (FMAs) em florestas de Araucaria angustifolia, visando a discriminar entre as comunidades de FMAs associadas com ecossistemas natural, implantado e impactado pela ação antrópica. Foram selecionados três ecossistemas representativos da região de Campos do Jordão (estado de São Paulo), sendo: (i) Floresta nativa com predominância de araucária, em clímax, sem interferência antrópica (FN); (ii) Floresta de araucária introduzida em 1959 (RE); e (iii) Floresta de araucária introduzida em 1958, submetida a uma queima acidental em julho de 2001 (RF). As coletas de solo rizosférico foram realizadas, na profundidade $0-20 \mathrm{~cm}$, ao redor de cada árvore e a $2 \mathrm{~m}$ do tronco, nos meses de maio e outubro de 2002. Determinaram-se a densidade, diversidade, esporulação, colonização radicular e realizou-se a identificação morfológica dos FMAs. Os índices ecológicos R (Riqueza de espécies), Is (índice de dominância de Simpson) e H (índice de diversidade de Shannon) foram calculados. Os dados foram submetidos à análise univariada (two-way ANOVA) e análise de correspondência (AC). Considerando os dois períodos de amostragem e os três ecossistemas estudados, foram identificadas 26 espécies de FMAs, sendo os gêneros Acaulospora e Glomus os mais freqüentes. Não houve diferenças para R, Is e H entre as três áreas estudadas. A AC demonstrou que houve separação espacial entre as três áreas e quais foram às espécies de FMAs preferencialmente associadas em cada área.

Palavras-chaves: FMA, pinheiro brasileiro, diversidade, densidade de esporos, fogo acidental 


\section{INTRODUCTION}

Arbuscular mycorrhizal fungi (AMF) (order Glomales, phylum Glomeromycota) are obligate symbionts that colonize roots and form a symbiotic association with most of terrestrial plants (Smith \& Read, 1997). In the establishment of this symbiosis, plants are benefited by greater $\mathrm{P}$ absorption, while the fungi extract carbon from the plant for their development and sporulation. AMF and their interactions contribute to cycling, transport of nutrients (Chen et al., 2005), and plant productivity and are considered important components for the sustainability of agricultural systems (Barea, 1991; Smith \& Read, 1997). They are distributed through the most diverse ecosystems (Janos, 1980; Klironomos et al., 1999), and can determine the structure and composition of plant communities (Heijden et al., 1998; Klironomos et al., 2000; O’Connor et al., 2002; Heijden, 2002); plant communities, in turn, can affect the survival and reproduction of AMF communities (Sanders \& Fitter, 1992; Eom et al., 2000). Any soil disturbance, such as the occurrence of fire, may change the structure of AMF or even decrease the number of AMF species (Moreira et al., 2007a). However, the structure of AMF communities and distribution in natural Araucaria ecosystems in Brazil is little known and has not been sufficiently studied.

AMF species are identified based on morphological characteristics of spores, and thus are very important to determine the AMF distribution (Smith \& Read, 1997). Variations in moisture (Anderson et al., 1983), organic matter content (Klironomos et al., 1993), pH (Robson \& Abbott, 1989), and temperature (Koske, 1987) may affect abundance of AMF spores.

Nowadays, natural Araucaria angustifolia (Bertoloni) Otto Kuntze forests are threatened in Brazil (IBAMA, 1992) and very little is known about the diversity of microorganisms associated with this ecosystem (Moreira et al., 2006). However, several studies on AMF in Araucaria angustifolia have been carried out (Milanez \& Monteiro, 1950; Oliveira \& Ventura, 1952; Bononi et al., 1989; Breuninger et al., 2000; Moreira-Souza et al., 2003, Moreira et al., 2006; Moreira et al., 2007a). Moreira-Souza \& Cardoso (2002) demonstrated that Araucaria is a mycotrophic plant. The parameters that are modified by disturbances in native rain forests in Mexico were studied by Violi et al. (2008).

Spore abundance and root colonization data from this sampling has been published elsewhere (Moreira et al., 2006). The focus with this present study was to survey data on the diversity of AMF in Araucaria angustifolia forests, in order to learn whether it is pos- sible to discriminate between the AMF communities associated with natural, introduced, and impacted-byanthropogenic-action ecosystems, using univariate (two-way ANOVA) and correspondence analysis (CA) to determine the relative importance of time and space on differences observed, and focus more of the discussion on the differences in morphotypes among the three ecosystems.

\section{MATERIALAND METHODS}

\section{Study sites, treatments and sampling}

The sampling sites were in native and replanted Araucaria angustifolia forests at Parque Estadual de Campos do Jordão (PECJ, a State Park) (22 ${ }^{\circ} 44^{\prime} \mathrm{S}$ and $45^{\circ} 30^{\prime}$ W), located in Campos do Jordão, State of São Paulo, Brazil. The climate is characterized as subtropical (upland), mesothermal, and humid (Köppen). The mean annual rainfall is $1,804 \mathrm{~mm}$, and the mean temperature ranges from $17.5^{\circ} \mathrm{C}$ in the hottest month (February) to $11.5^{\circ} \mathrm{C}$ in the coolest month (June), with the occurrence of below-freezing temperatures. In May (autumn, cool and dry), maximum temperature was $23.2^{\circ} \mathrm{C}$ and the lowest only $0.9^{\circ} \mathrm{C}$. In October (spring, warmer and wet), maximum temperature was $35.1^{\circ} \mathrm{C}$ and the lowest $5.2^{\circ} \mathrm{C}$ (Moreira et al., 2006; Baretta et al., 2007).

In each ecosystem five Araucaria trees were randomly selected. Three soil cores were taken around each of five trees in order to assess the within-tree variability (15 sampling points for ordination analysis). The studied ecosystems included: (i) a native climax forest with predominance of Araucaria trees (approximately 100-year-old trees), without anthropogenic interference (NF), (ii) a reforested area with Araucaria, introduced in 1959 (RE), and (iii) a reforested area introduced in 1958, submitted to accidental fire in July, 2001 (RF). The soils are clayey-textured with similar toposequences, elevations, and solar exposition in the three ecosystems. More detailed information can be obtained in Moreira-Souza et al. (2003) and Moreira et al. (2006). There were more similar features between the replanted (RE) and the burned area (RF). However, the RF area had been burned more than one year previous to our analyses, and the general features were of recuperation of a wide variety of arboreal plants, more similar to NF, and different from RE, that presented a very uniform cover of $A$. angustifolia. The fire apparently was not of a very great intensity, since most trees survived and only the herbaceous vegetation was eliminated. Also, there is no information available about the effect of burning in these forests.

Due to the high variability of these ecosystems and the very little knowledge on local AMF, we reduced 
the sampling areas to approximately 0.5 ha in order to avoid some critical site characteristics like slope, differential solar exposure, variation in soil characteristics and to minimize confounding effects. For these reasons we could not find adequate replicate areas to be studied, and we were limited to replications inside each area. We took this fact into account in the interpretation of our results, discussion and conclusion.

\section{Samplings}

Samples were taken from 15 points at $0-20 \mathrm{~cm}$ depth, at the crown projection area, and $2 \mathrm{~m}$ away from trunk (three points per tree). The soil samples were placed in plastic bags for later determination of number of spores and AMF species identification. Each sample point was analyzed separately (three points per tree $\times$ five trees $=15$ sampling points for ordination analysis). The total number of spores in $100 \mathrm{~g}$ of dry soil was determined by wet sieving (Gerdemann \& Nicolson, 1963), based on a 100 g-aliquot for each point studied, followed by centrifugation in sucrose (Jenkins, 1964). The spores were counted under a stereoscopic microscope with $40 \mathrm{X}$ magnification, on plates containing concentric grooves. After the total number was obtained, the spores were separated into groups, according to their morphology. Spore abundance and root colonization data from this sampling has been published in Moreira et al. (2006).

\section{AMF identification}

The AMF spore groups were transferred and mounted onto semi-permanent slides, with polyvinyl alcohol and glycerol resin (PVLG) (Morton et al., 1993) and in Melzer's reagent (Koske \& Tessier, 1983). Identification was made at the species level using an optical microscope (100 to 400X magnification), with the aid of the Schenck \& Pérez (1990) manual, descriptions provided by the International Collection of Vesicular and Arbuscular Mycorrhizal Fungi (http:// invam.caf.wvu.edu) and the original species descriptions. The number of spores (NS) in $100 \mathrm{~g}$ dry soil was evaluated for each morphologically distinct AMF group. After AMF species identification, the following were determined: species richness (R), evaluated by the number of species present in 100g soil, Simpson's dominance index (Is) [Is $=1-\mathrm{L}$ ), where: $\mathrm{L}=\sum \mathrm{ni}$ (n1)/N(N-1); ni = density of each AMF species "i", $N=$ total number of species of AMF species], and Shannon's diversity index $(\mathrm{H})\left[\mathrm{H}=-\sum\right.$ (pi log pi), where: $\mathrm{pi}=\mathrm{ni} / \mathrm{N}$; $\mathrm{ni}=$ density of each AMF species, $\mathrm{N}=$ total number of species] (Odum (1983; Baretta et al., 2007).

\section{Statistical analysis}

The data for $\mathrm{R}$, Is and $\mathrm{H}$ were submitted to analy- ses of two-way ANOVA, using the SAS version 6.2 statistical program (SAS Institute, 1996), and means were compared by the LSD test $(p<0.05)$. NS data were also submitted to multivariate correspondence analysis (CA) (Braak, 1986; Baretta et al., 2006; Baretta et al., 2007), using the STATISTICA 6.0 software package (StatSoft, 2001). The relative spore frequency for each AMF species (RSF), [RSF = (number of spores/total number of AMF spores) $\times 100$ ] was also calculated for the studied ecosystems.

\section{RESULTS}

\section{AMF density and diversity}

The analysis of variance (two-way ANOVA) for species richness (R), Simpson's dominance index (Is), and Shannon's diversity index $(\mathrm{H})$ indicated (LSD test at $5 \%$ significance) that there was no difference between Araucaria ecosystems (Figures 1A, 1B and 1C). For RE, there were no differences between sampling periods, regarding $\mathrm{R}$, Is, and $\mathrm{H}$, while higher values were found for $\mathrm{H}$ and Is in May, in the areas NF and $\mathrm{RF}$. The higher Is denotes that higher dominance occurred during May by one or a few AMF species in NF (Figure 1B).

AMF species found in the NF and in both replanted areas (RE and RF), during both seasons, are presented in Table 1. Overall, 26 species of AM fungi (with a total of 1099 spores) were identified in the NF during both collection seasons. The species that appeared in NF only during the first sampling (May) were: Acaulospora gerdemannii, Acaulospora sp.3, Glomus sp.1, Scutellospora heterogama, and Scutellospora sp.3. In the second sampling (October), the exclusive species found were: Acaulospora scrobiculata, Gigaspora decipiens, G. gigantea, Glomus microcarpum, Scutellospora calospora and S. pellucida. These species in the first sampling belong to four genera: seven species in Acaulospora, three species in Glomus, four species in Scutellospora, and one in Entrophospora (Table 1). However, in the second sampling, the presence of one extra genus, Gigaspora, was observed. In the replanted areas (RE and RF), 13 and 16 species were found in May and 13 and 15 species were found in October, respectively. In RE and RF, the species were distributed among five genera in the first sampling (May): 7 and 5 Acaulospora; 1 and 1 Entrophospora; 3 and 4 Glomus; 1 and 2 Scutellospora; and 1 and 1 Gigaspora for the RE and RF areas, respectively. However, in the second collection (October), the species were distributed among 5 genera in $\mathrm{RE}$ and 4 genera in RF, as follows: 6 and 6 Acaulospora; 1 and 1 Entrophospora; 3 and 4 Glomus; 3 and 2 Scutellospora; and 3 and 0 Gigaspora, 

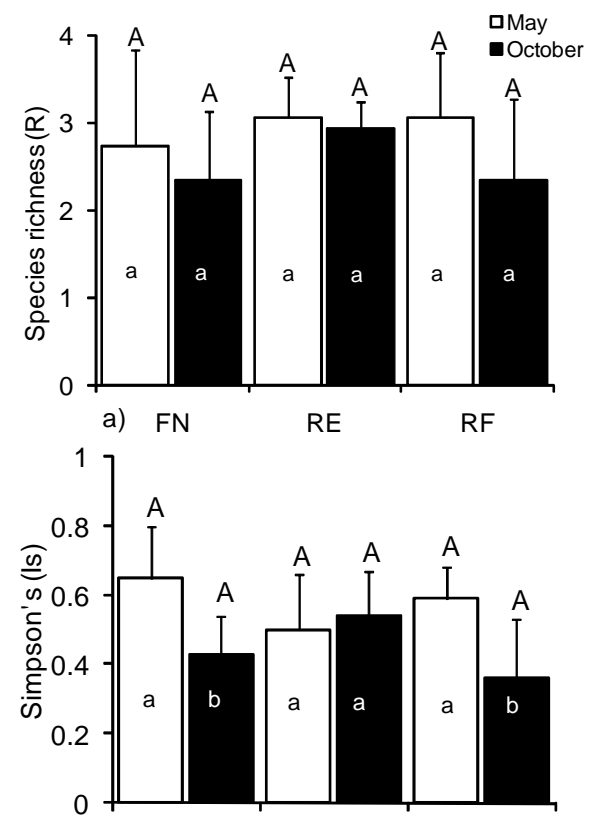

b)

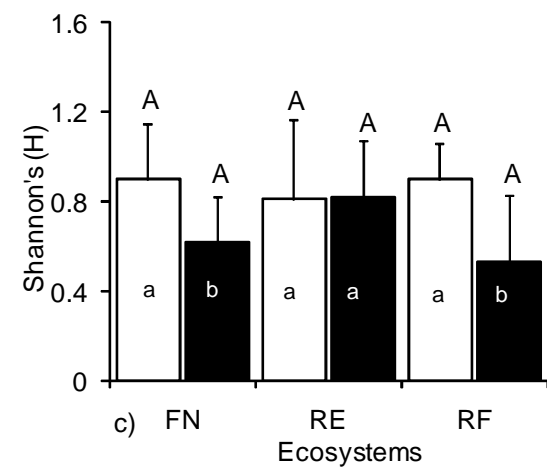

Figure 1 - Species richness (R), Simpson's (Is) and Shannon's $(\mathrm{H})$ diversity indices of AMF in native (FN), introduced (RE), and impacted-by-accidental-fire (RF) Araucaria angustifolia ecosystems, in May ( $\square$ ) and October (ם), 2002. Campos do Jordão, SP, Brazil. Vertical bars (T) Standard deviation. Results of twoway ANOVA. Capital letters compare ecosystems during the same period, while small letters compare the same ecosystem at different periods. $(p<0.05)$ by the LSD test.

respectively. Glomus diaphanum was only found in the $\mathrm{RF}$ and only at the first sampling. In native forest, $G$. etunicatum, G. macrocarpum, E. colombiana and Scutellospora sp.1 presented high frequencies in May, while A. sp.1, S. sp.1, and Gigaspora decipiens were more frequent in October. For the replanted Araucaria, the greatest RSF values were for A. mellea and $G$. margarita in May, and A. mellea and Scutellospora sp.3 in October. Finally, in the replanted and burned area, there was always a predominance of the two most frequent species of Glomus: G. etunicatum and G. macrocarpum in both seasons. Scutellospora sp.3 achieved an RSF somewhat over 10, only in October, in RE and RF.

\section{Correspondence analysis (CA)}

The relationship between AMF species and the three Araucaria ecosystems studied was determined by means of an ordination created by correspondence analysis (CA). This ordination method is summarized in a graph (Figures 2 and 3) containing perpendicular dimensions (dimension 1 and 2), representing the multidimensional variation of a set of response variables (AMF species) in the different Araucaria ecosystems studied (Braak, 1986; Baretta et al., 2006; Baretta et al., 2007). The CA result for the first sampling season (May) indicated that separation occurred between the native (FN), introduced (RE), and impacted-by-fire Araucaria ecosystem (RF) (Figure 2). This separation was $78.8 \%$ explained (78.8\% total variability) by dimension 1 and only $11.0 \%$ by dimension 2 . Therefore, dimension 1 matters much more than dimension 2 . This multivariate analysis showed the greater or the smaller association of each AMF species with each ecosystem. In this respect, the AMF species showing strong associations and contributing the most toward the FN ecosystem separation were, for example, Scutellospora sp.1, Scutellospora sp.3, S. calospora, S. heterogama,

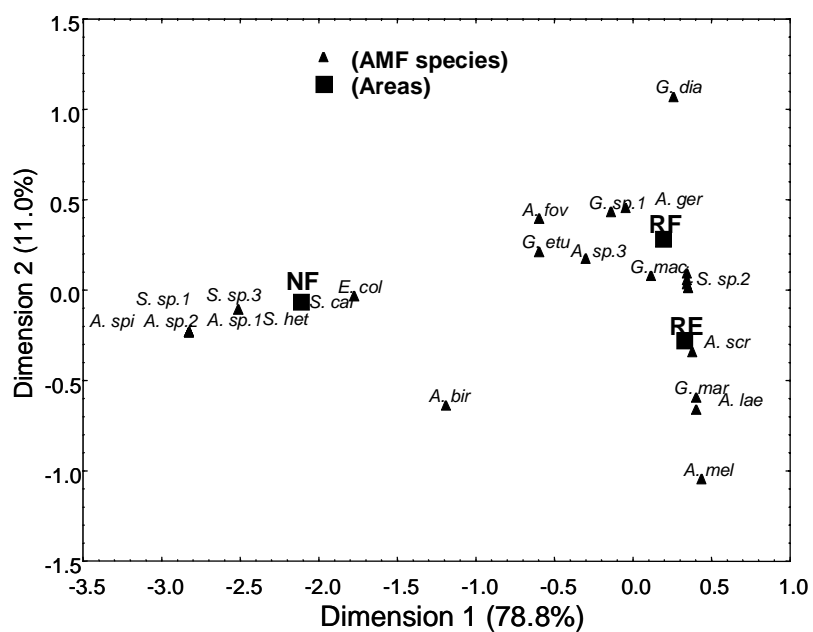

Figure 2 - Relation between dimensions 1 and 2 of the correspondence analysis (CA) for native (NF), reforested (RE), and impacted-by-fire (RF) Araucaria angustifolia ecosystems and AMF species, in the first sampling (May, $\mathrm{n}=15$ ). Campos do Jordão, SP, 2002. A. bir =Acaulospora bireticulata; $A$. fov $=$ A. foveata; A. ger $=A$ gerdemannii; A. lae = A. laevis; A. mel = A. mellea; A. $s c r=$ A. scrobiculata; A. spi = A. spinosa; A. sp.1 = Acaulospora sp.1; A. sp.2 = Acaulospora sp.2; A. sp.3 = Acaulospora sp.3; E. col = Entrophospora colombiana; G. mar = Gigaspora margarita; $G$. dia = Glomus diaphanum; G. etu = G. etunicatum; G. mac $=$ G. macrocarpum; G. sp.1 = Glomus sp. $1 ;$ S. cal = Scutellospora calospora; S. het $=$ S. heterogama; S. sp.1 = Scutellospora sp.1; S. sp.2 = Scutellospora sp.2; S. sp.3= Scutellospora sp.3. 
Table 1 - Number of spores (NS) and relative frequency of AMF spores (RSF) in native (NF), introduced (RE), and impactedby-fire (RF) Araucaria angustifolia ecosystems, in May and October, 2002. Campos do Jordão, São Paulo state, Brazil. $(\mathrm{n}=15)$.

\begin{tabular}{|c|c|c|c|c|c|c|c|c|c|c|c|c|}
\hline \multirow{3}{*}{ AMF Species } & \multicolumn{6}{|c|}{ May } & \multicolumn{6}{|c|}{ October } \\
\hline & \multicolumn{2}{|c|}{ Native } & \multicolumn{2}{|c|}{ Reforested } & \multicolumn{2}{|c|}{ Refor.+Fire } & \multicolumn{2}{|c|}{ Native } & \multicolumn{2}{|c|}{ Reforested } & \multicolumn{2}{|c|}{ Refor.+Fire } \\
\hline & NS & RSF & NS & RSF & NS & RSF & NS & RSF & NS & RSF & NS & RSF \\
\hline Acaulospora bireticulata Rothwell \& Trappe & 2 & 1.59 & 2 & 0.95 & -1 & - & 3 & 1.54 & - & - & - & - \\
\hline A. foveata Trappe \& Janos & 4 & 3.17 & 2 & 0.95 & 8 & 3.67 & 5 & 2.56 & 8 & 4.10 & 6 & 3.87 \\
\hline A. gerdemannii Schenck \& Nicol. & 2 & 1.59 & 4 & 1.90 & 12 & 5.50 & - & - & 2 & 1.03 & 2 & 1.29 \\
\hline A. laevis Gerd. Trappe & - & - & 18 & 8.57 & 4 & 1.83 & - & - & - & - & - & - \\
\hline A. mellea Spain \& Schenck & - & - & 26 & 12.38 & - & - & - & - & 20 & 10.26 & 4 & 2.58 \\
\hline A. scrobiculata Trappe & - & - & 8 & 3.81 & 4 & 1.83 & 3 & 1.54 & 10 & 5.13 & - & - \\
\hline A. spinosa Walker \& Trappe & 8 & 6.35 & - & - & - & - & 2 & 1.03 & - & - & 2 & 1.29 \\
\hline Acaulospora. sp. 1 & 6 & 4.70 & - & - & - & - & 40 & 20.51 & 4 & 2.05 & 2 & 1.29 \\
\hline Acaulospora sp. 2 & 6 & 4.76 & - & - & - & - & 2 & 1.03 & 12 & 6.15 & 8 & 5.16 \\
\hline Acaulospora sp. 3 & 4 & 3.17 & 6 & 2.86 & 10 & 4.59 & - & - & - & - & - & - \\
\hline Entrophospora colombiana Spain \& Schenck & 24 & 19.05 & 4 & 1.90 & 8 & 3.67 & 4 & 2.05 & 5 & 2.56 & 2 & 1.29 \\
\hline Gigaspora decipiens Hall \& Abott & - & - & - & - & - & - & 22 & 11.28 & - & - & - & - \\
\hline G. gigantea (Nicol. \& Gerd.) Gerd. \& Trappe & - & - & - & - & - & - & 3 & 1.54 & 2 & 1.03 & - & - \\
\hline G. margarita Becker \& Hall & - & - & 24 & 11.43 & 10 & 4.59 & - & - & 2 & 1.03 & - & - \\
\hline Gigaspora sp.1 & - & - & - & - & - & - & - & - & 2 & 1.03 & - & - \\
\hline Glomus diaphanum Morton \& Walker & - & - & - & - & 6 & 2.75 & - & - & - & - & - & - \\
\hline G. etunicatum Becker \& Gerd. & 18 & 14.29 & 20 & 9.52 & 30 & 13.76 & 32 & 16.41 & 58 & 29.74 & 3 & 1.94 \\
\hline G. macrocarpum Tulasne \& Tulasne & 14 & 11.11 & 84 & 40.00 & 100 & 45.87 & 14 & 7.18 & 34 & 17.44 & 94 & 60.65 \\
\hline G. microcarpum Tulasne \& Tulasne & - & - & - & - & - & - & 11 & 5.64 & - & - & 6 & 3.87 \\
\hline Glomus sp.1 & 4 & 3.17 & 6 & 2.86 & 18 & 8.26 & - & - & 4 & 2.05 & 6 & 3.87 \\
\hline Scutellospora calospora Walker \& Sanders & 8 & 6.35 & - & - & - & - & 8 & 4.10 & - & - & 2 & 1.29 \\
\hline $\begin{array}{l}\text { S. heterogama (Nicol. \& Gerd.) Walker \& } \\
\text { Sanders }\end{array}$ & 2 & 1.59 & - & - & - & - & - & - & - & - & - & - \\
\hline $\begin{array}{l}\text { S. pellucida (Nicol. \& Schenck) Walker \& } \\
\text { Sanders }\end{array}$ & - & - & - & - & - & - & 4 & 2.05 & - & - & - & - \\
\hline Scutellospora sp.1 & 22 & 17.46 & - & - & 2 & 0.92 & 42 & 21.54 & 6 & 3.08 & 2 & 1.29 \\
\hline Scutellospora sp. 2 & - & - & 6 & 2.86 & 6 & 2.75 & - & - & 2 & 1.03 & - & - \\
\hline Scutellospora sp. 3 & 2 & 1.59 & - & - & - & - & - & - & 24 & 12.31 & 16 & 10.32 \\
\hline
\end{tabular}

${ }^{1}$ Absence of spores

Acaulospora sp.1, Acaulospora sp.2, A. spinosa, and Entrophospora colombiana. Acaulospora bireticulata, which stands between the three ecosystems studied; however, is not associated with any specific ecosystem (Figure 2). Several species also overlapped (or were near one another), indicating similarity. Thus, Acaulospora sp.1, Acaulospora sp.2, A. spinosa, Scutellospora sp.1, Scutellospora sp.3, S. calospora and $S$. heterogama were abundant in FN and rare or absent in RE and RF, the reverse being true for Acaulospora mellea and A. bireticulata (Figure 2 and Table 1).

In the second season (October), there was again a separation among the ecosystems. Dimension 1 explained $54.6 \%$ of the separation found among the three ecosystems, while dimension 2 explained $25.0 \%$ of the variation (Figure 3 ). In this case, there was a smaller difference between dimension 1 and 2 (54.6 and 25.0\% of total data variability) than in Figure 2 (78.8 and
$11.0 \%$ of total data variability); thus, dimension 2 was more important in October than it was in May. However, in October (second sampling) (Figure 3), the behavior, association, and contribution of each AMF species in the separation of ecosystems was different from the first sampling (May) (Figures 2 and 3). In this regard, it was found for the FN ecosystem, for example, that the species Scutellospora sp.1, Acaulospora sp.1, Gigaspora decipiens, and S. pellucida were associated together to a higher degree and contributed more to the separation, in relation to the other species. On the other hand, the species Acaulospora bireticulata, Glomus sp.1, G. macrocarpum, G. microcarpum, Scutellospora sp.3 and $S$. calospora were more associated with the introduced Araucaria ecosystem that was accidentally burned (RF). Acaulospora gerdemannii, A. scrobiculata, A. mellea, Acaulospora sp.2, A. foveata, Entrophospora colombiana, Glomus sp.1, G. etunicatum, Gigaspora 


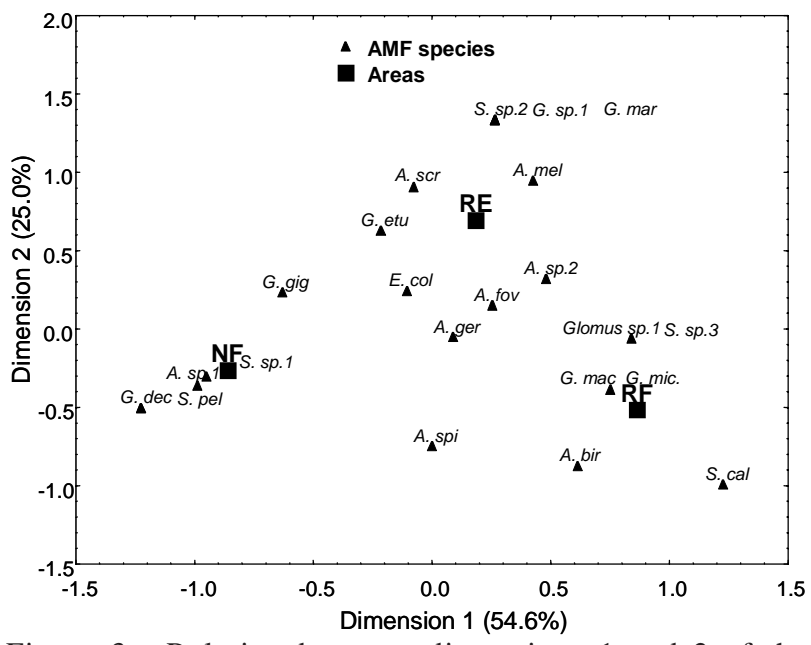

Figure 3 - Relation between dimensions 1 and 2 of the correspondence analysis (CA) for native (FN), introduced (RE), and impacted-by-fire (RF) Araucaria angustifolia ecosystems and AMF species, in the second sampling (October, $\mathrm{n}=15$ ). Campos do Jordão, SP, 2002. A. bir =Acaulospora bireticulata; $A$. fov = A. foveata; A. ger $=A$ gerdemannii; $A$. mel = A. mellea; $A$. scr $=A$. scrobiculata; $A$. spi $=$ A. spinosa; $A$. sp. $1=$ Acaulospora sp.1; A. sp.2 = Acaulospora sp.2; E. $\mathrm{col}=$ Entrophospora colombiana; $\mathrm{G}$. dec $=$ Gigaspora decipiens; G. gig = G. gigantea; G. mar = G. margarita; G. sp.1 = Gigaspora sp.1; G. etu = Glomus etunicatum; G. mac = G. macrocarpum; $G$. mic $=$ G. microcarpum; $S$. cal = Scutellospora calospora; $S$. pel $=$ S. pellucida; $S$. sp.1 $1=$ Scutellospora sp.1; S. sp.2 = Scutellospora sp.2; . sp. 3 = Scutellospora sp.3.

margarita and Scutellospora sp.2 were, however, more closely associated with the introduced Araucaria ecosystem that was not impacted by fire (RE) (Figure 3).

\section{DISCUSSION}

The predominance of the genera Glomus and Acaulospora was detected in all three areas. In other studies about $A$. angustifolia forests, Bononi et al. (1989), Breuninger et al. (2000) and Moreira-Souza et al. (2003) have also reported that Acaulospora and Glomus are the most frequent genera. Such predominance has been observed also in a tropical forest study in China (Zhao et al., 2001). In the present work, the most common species (Acaulospora foveata, Entrophospora colombiana, Glomus etunicatum, and G. macrocarpum) were also shared between the three ecosystems investigated (Table 1), although only the two last ones showed very high relative spore frequencies (RSF) in almost every area and season.

Differences in AMF communities confirmed by multivariate analysis led us to consider that there are great differences in the behavior of AMF in the three ecosystems, especially when comparing the two seasons (Figures 2 and 3). AMF sporulation at the same sampling point is very dynamic in relation to different seasons of the year; therefore number of spores may not always be a reliable parameter to define the composition of the AMF community in an ecosystem (Moreira et al., 2007a). There are fungi that sporulate more, while others sporulate less, and others yet, do not sporulate or do so only during certain periods of the year (Table 1). Repeated sampling several times during the year could provide a more complete picture of this variability, as discussed in Moreira et al. (2007b). Different AMF may have different carbon and other nutrient requirements for sporulation, and this may explain differing AMF phenologies (Violi et al., 2008). Bever et al. (1996) reported that host plants determine differences as to when different AMF taxa sporulated. Schenck et al. (1989) compared species diversity in a "cerrado" soil in Brazil, and found a higher number of spores in an agroecosystem than in a native ecosystem, although many studies report that AMF diversity decreases when a natural system is converted into an agroecosystem (Sieverding, 1991).

The CA indicated that the presence or absence of a given AMF species could have been influenced by stress situations, such as anthropogenic perturbations. Nevertheless, stress or anthropogenic interference is extremely difficult to quantify in ecosystems. The greater or the smaller association of a given AMF species in each forest ecosystem varies both spatially and temporally, as a function of the different seasons of the year. Thus, low temperatures, for example, may affect sporulation (Koske, 1987). Many ecological characteristics can be modified by anthropogenic interference, often in a way that imposes severe limitations to the survival. The life cycle of each AMF species may be influenced by environmental factors and also by the diversity and phenology of local plants; therefore, each site possesses specific properties which will determine species density.

AMF spore density and species diversity are indirectly related to the ecological conditions of each ecosystem (Maia \& Trufem, 1990). Thus, not only may "temporal niche partitioning" be important to the maintenance of AMF diversity, as proposed by Pringle \& Bever (2002), but AMF seasonal patterns in sporulation may "reassemble" or "shift" in response to changes to host plant community composition such that individual AMF taxa sporulate in different seasons.

Our observations suggest that some of the modifications in the AMF communities may have been partially due to anthropogenic interference occurring in the Araucaria forests. Nevertheless, it looks encour- 
aging, that after very long periods (more than 50 years) even reforested areas seem to have stabilized ecologic features. Perhaps an accidental fire may be overcome in a few years. According to this reasoning, the maintenance of the few still preserved native forests and also the replanting of new Araucaria seedlings assume great importance for the conservation of this species and of the symbiotic AM fungi.

\section{ACKNOWLEDGEMENTS}

M. Moreira and D. Baretta thank "Fundação de Amparo à Pesquisa do Estado de São Paulo (FAPESP)" for the post-doctoral grant (process no. 01/13229-9 and process no. 2007/05637-6). We acknowledge the financial support of this project by BIOTA/FAPESP (Process 01/05146-6), the Biodiversity Virtual Institute Program (www.biotasp.org.br) and IBAMA for the required collection permit (proceeding no. 02027.002353/05-94). E.J.B.N. Cardoso and S.M. Tsai thank "Conselho Nacional de Pesquisas (CNPq)" for the research fellowships. The authors thank the Campos do Jordão State Park and the Environment Secretariat of the State of São Paulo for authorizing the collection of plant material (Proceeding 40405/98 COTEC 079/98). Special thanks are due to Denise Mescolotti and Luis Fernando Baldesin for technical assistance. We acknowledge Dr. Lucero Mariani (ECODIV/University of Rouen, France) and anonymous referees for their critical and helpful comments.

\section{REFERENCES}

ANDERSON, R.C.; LIBERTA, A.E.; DICKMAN, L.A.; KATZ, A.J. Spatial variation in vesicular arbuscular mycorrhiza spore density. Bulletin of the Torrey Botanical Club, v.110, p.519-525, 1983.

BAREA, J.M. Vesicular arbuscular mycorrhizae as modifiers of soil fertility. Advance Soil Science, v.15, p.1-40, 1991.

BARETTA D.; BRESCOVIT, A.D.; KNYSAK, I.; CARDOSO, E.J.B.N. Trap and soil monolith sampled edaphic spiders (Arachnida: Araneae) in Araucaria angustifolia forest. Scientia Agricola, v.64, p.375-383, 2007.

BARETTA, D.; MAFRA, A.L.; SANTOS, J.C.P.; AMARANTE, C.V.T.; BERTOL, I. Análise multivariada da fauna edáfica em diferentes sistemas de preparo e cultivo do solo. Pesquisa Agropecuária Brasileira, v.41, p.1675-1679, 2006.

BEVER, J.D.; MORTON, J.B.; ANTONOVICS, J.; SCHULTZ, P.A. Host-dependent sporulation and species diversity of arbuscular mycorrhizal fungi in a mown grassland. Journal of Ecology, v.84, p.71-82, 1996.

BONONI, V.L.R.; GRANDI, R.A.P.; LOPES, S.A.R.; RODRIGUES, E.; FONSECA, M.P. Micorrizas vesiculo-arbusculares em Araucaria angustifolia (Bert.) O. Ktze In: REUNIÃO BRASILEIRA SOBRE MICORRIZAS, 3., Piracicaba, 1989. Programas e Resumos. Piracicaba: CENA/ESALQ, 1989. 104p.

BRAAK, C.J.F. ter. Canonical correspondence analysis: a new eigenvector technique for multivariate direct gradient analysis. Ecology, v.67, p.1167-1179, 1986.
BREUNINGER, M.; EINING, W.; MAGEL, E.; CARDOSO, E.; HAMPP, R. Mycorrhiza of Brazil Pine (Araucaria angustifolia Bert. O. Ktze.). Plant Biology, v.2, p.4-10, 2000.

CHEN, X.; TANG, J.; ZHI, G.; HU, S. Arbuscular mycorrhizal colonization and phosphorus acquisition of plants: effects of coexisting plant species. Applied Soil Ecology, v.28, p.259269, 2005.

EOM, A.H.; HARTNETT, D.C.; WILSON, G.W.T. Host plant species effects on arbuscular mycorrhizal fungal communities in tallgrass prairie. Oecologia, v.122, p.435-444, 2000.

GERDEMANN, J.W.; NICOLSON, T.H. Spores of mycorrhizal Endogone species extracted from soil by sieving and decanting. Transactions British Mycological Society, v.46, p.235-246, 1963.

HEIJDEN, M. van der; KLIRONOMOS, J.; URSIC, M.; MOUTOGLIS, P.; STREITWOLF-ENGEL, R.; BOLLER, T.; WIEMKEN, A.; SANDERS, I. Mycorrhizal fungal diversity determines plant biodiversity, ecosystem variability and productivity. Nature, v.396, p.69-72, 1998.

HEIJDEN, M.G.A.van der. Arbuscular mycorhizal fungi as a determinant of plant diversity; in search of underlying mechanisms and general principles. In: HEIJDEN, M.G.A van der; SANDERS, I. (Ed.) Mycorrhizal ecology: ecologycal studies. Berlin: Springer-Verlag, 2002. p.243-265.

INSTITUTO BRASILEIRO DO MEIO AMBIENTE E DOS RECURSOS NATURAIS RENOVÁVEIS - IBAMA. Lista oficial de espécies da flora brasileira ameaçadas de extinção. Portaria IBAMA n.06 N, de 15 de janeiro de 1992. Diário Oficial da União, Brasília, 1992, p.870-872.

JANOS, D.P. Mycorrhizae influence tropical succession. Biotropica, v.12, p.56-64, 1980.

JENKINS, W.R. A rapid centrifugation technique for separating nematodes from soil. Plant Disease Report, v.48, p.692, 1964.

KLIRONOMOS, J.N.; BEDNARCZUK, E.M.; NEVILLE, J. Reproductive significance of feeding on saprobic and arbuscular mycorrhizal fungi by the collembolan, Folsomia candida. Functional Ecology, v.13, p.756-761, 1999.

KLIRONOMOS, J.N.; McCUNE, J.; HART, M.; NEVILLE, J. The influence of arbuscular mycorrhizae on the relationship between plant diversity and productivity. Ecology Letters, v.3, p.137$141,2000$.

KLIRONOMOS, J.N.; MOUTOGLIS, P.; KENDRICK, B.; WIDDEN, P. A comparison of spatial heterogeneity of vesiculararbuscular mycorrhizal fungi in two maple-forest soils. Canadian Journal Botany, v.71, p.1472-1480, 1993.

KOSKE, R.E. Distribution of VA mycorrhizal fungi along a latitudinal temperature gradient. Mycologia, v.79, p.55-68, 1987.

KOSKE, R.E.; TESSIER, B. A convenient, permanent slide mounting medium. Mycological Society of America News Letter, v.34, p.59, 1983.

MAIA, L.C.; TRUFEM, S.F.B. Fungos micorrízicos vesículoarbusculares em solos cultivados no Estado do Pernambuco, Brasil. Revista Brasileira de Botânica, v.13, p.89-95, 1990.

MILANEZ, F.R.; MONTEIRO NETO, H. Nota prévia sobre micorriza no pinho do Paraná. Arquivos do Serviço Florestal, v.4, p.87-93, 1950.

MOREIRA, M.; BARETTA, D.; TSAI, S.M.; CARDOSO, E.J.B.N. Spore density and root colonization by arbuscular mycorrhizal fungi in preserved or disturbed Araucaria angustifolia (Bert.) O. Ktze. ecosystems. Scientia Agrícola, v.63, p.380-385, 2006.

MOREIRA, M.; BARETTA, D.; TSAI, S.M.; GOMES-DA-COSTA, S.M.; CARDOSO, E.J.B.N. Biodiversity and distribution of arbuscular mycorrhizal fungi in Araucaria angustifolia forest. Scientia Agricola, v.64, p.393-399, 2007a.

MOREIRA, M.; NOGUEIRA, M.A.; TSAI, S.M.; GOMES-DACOSTA, S.M.; CARDOSO, E.J.B.N. Sporulation and diversity of arbuscular mycorrhizal fungi in Brazil Pine in the field and in the greenhouse. Mycorrhiza, v.17, p.519-526, 2007b. 
MOREIRA-SOUZA, M.; CARDOSO, E.J.B.N. Dependência micorrízica de Araucaria angustifolia (Bert.) O. Ktze. sob doses de fósforo. Revista Brasileira de Ciência do Solo, v.26, p.905-912, 2002.

MOREIRA-SOUZA, M.; TRUFEM, S.F.B.; GOMES-DA-COSTA, S.M.; CARDOSO, E.J.B.N. Arbuscular mycorrhizal fungi associated with Araucaria angustifolia (Bert.) O. Ktze. Mycorrhiza, v.13, p.211-215, 2003.

MORTON, J.B.; BENTIVENGA, S.P.; WHEELER, W.W. Germplasm in the international Collection of Arbuscular and Vesicular Arbuscular Mycorrhizal Fungi (INVAM) and procedures for culture development, documentation and storage. Mycotaxon, v.48, p.491-528, 1993.

O’CONNOR, P.J.; SMITH, S.E.; SMITH, F.A. Arbuscular mycorrhizas influence plant diversity and community structure in a semiarid herbland. New Phytologist, v.154, p.209-218, 2002.

ODUM, E.P. Ecologia. Rio de Janeiro: Guanabara Koogan, 1983. 434p.

OLIVEIRA, M.; VENTURA, A. A ocorrência de micorriza em Araucaria angustifolia (Bert.) O. Ktze e Podocarpus lamberti. São Paulo: Serviço Florestal, 1952. 5p. (Edições e propaganda, 25).

PRINGLE, A.; BEVER, J.D. Divergent phenologies may facilitate the coexistence of arbuscular mycorrhizal fungi in a North Carolina grassland. American Journal of Botany, v.89, p.1439-1446, 2002.

ROBSON, A.D.; ABBOTT, L.K. The effect of soil acidity on microbial activity in soils. In: ROBSON, A.D. (Ed.) Soil acidity and plant growth. New York: Academic Press, 1989. p.139165

SANDERS, I.R.; FITTER, A.H. The ecology and functioning of vesicular arbuscular mycorrhizas in coexisting grassland species: Seasonal patterns of mycorrhizal occurrence and morphology. New Phytologist, v.120, p.517-524, 1992.
SAS INSTITUTE. SAS/STAT: release 6.2. Cary: SAS Institute, 1996.

SCHENCK, M.C.; SIQUEIRA, J.O.; OLIVEIRA, E. Changes in the incidence of VA mycorrhizal fungi with changes in ecosystems. In: VANCURA, V.; KUNC, E. (Ed.) Interrelationships between microorganisms and plants in soil. New York: Elsevier, 1989. p.125-129.

SCHENCK, N.C.; PÉREZ, Y. Manual for the identification of VA mycorrhizal fungi. 3.ed. Gainesville: Synergistic, 1990 250p.

SIEVERDING, E. Vesicular arbuscular mycorrhiza management in tropical agrosystems. Eschborn: GTZ, 1991. 371p.

SMITH, S.E.; READ, D.J. Mycorrhizal symbiosis. 2 ed. New York: Academic Press, 1997. p.11-32.

STATSOFT . STATISTICA (data analysis software system), version 6. Tulsa, 2001.

VIOLI, H.A.; BARRIENTOS-PRIEGO, A.; WRIGTH, S.F.; ESCAMILLA-PRADO, E.; MORTON, J.B.; MENGE, J.A.; LOVATT, C.J. Disturbance changes arbuscular mycorrhizal fungal phenology and soil glomalin concentrations but not fungal spore composition in montane rainforests in Veracruz and Chiapas, Mexico. Forest Ecology and Management, v.254, p.276290, 2008.

ZHAO Z-W.; XIA, Y-M.; QIN, X-Z.; LI, X-W.; CHENG, L-Z.; SHA, T.; WAN, G-H. Arbuscular mycorrhizal status of plants and the spore density of arbuscular mycorrhizal fungi in the tropical rain forest of Xishuangbanna, southwest China. Mycorrhiza, v.11, p.159-162, 2001

Received February 13, 2008

Accepted April 01, 2009 